\title{
Congenital hypothyroidism from complete iodide transport defect: long-term evolution with iodide treatment
}

\author{
R. Albero, ${ }^{1}$ A. Cerdan ${ }^{1}$ and F. Sanchez Franco ${ }^{2}$

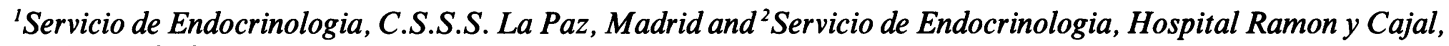 \\ 28034 Madrid, Spain.
}

\begin{abstract}
Summary: Hypothyroidism from iodide transport deficiency is a rare disease, especially when found in two affected siblings. Treatment with high doses of iodide has been recommended, but no long term results have been reported.

Two siblings with congenital hypothyroidism due to total failure to transport iodide have been followed up during twelve and a half years of treatment with oral potassium iodide.

Iodine doses varied between 10.3 and $22 \mathrm{mg} /$ day, and serum total iodine concentrations between 100 and $210 \mu \mathrm{g} / \mathrm{dl}$. Total triiodothyronine $\left(T_{3}\right)$, thyroxine $\left(T_{4}\right)$ and free $T_{4}$ were in the normal range during the time of study. Basal thyroid stimulating hormone (TSH) and maximum TSH response to thyrotophin releasing hormone (TRH) were also in the range of normal values. These data along with clinical findings confirmed the potential usefulness of iodine in hypothyroidism due to complete iodide transport defect.
\end{abstract}

\section{Introduction}

Among the different types of congenital hypothyroidism due to an alteration in thyroid hormone biosynthesis described by Stanbury \& Dumont,' one of the less frequent is that originating from the failure of the thyroid cell to transport iodide. In this case, the gland loses the capacity to concentrate iodide against chemical and electrical gradient. This lowers the glandular content of iodide and leads to a defect in thyroid hormone biosynthesis. The number of cases reported with this defect is $22,,^{2-21}$ including total or partial defects.

Treatment of these patients has not been definitively established. ${ }^{1,19}$ High doses of iodide have been recommended to increase the plasma/thyroid gradient of inorganic iodine and consequently raise the iodide intra-thyroidal concentration by simple diffusion. ${ }^{5,16}$ This would permit thyroid hormone synthesis in a normal way. Long term treatment doses, along with possible side effects on thyroid size and function are not exactly known. On the other hand, iodide itself has been involved in potentially beneficial effects. ${ }^{25}$

Two siblings with congenital hypothyroidism due to total failure to transport iodide are reported here. Their initial evaluation was done in 1973, followed up by twelve and a half years of treatment with high doses of oral potassium iodide (KI).

Correspondence: F. Sanchez Franco, M.D., Ph.D.

Accepted: 15 June 1987

\section{Material and methods}

\section{Patients}

Patient A was a 15 year old boy with goitre at the beginning of the study in 1973. His mother and maternal aunt had normofunctional goitre, and a sister (patient B) had congenital hypothyroidism; two other brothers were in good health. His parents were not consanguinous. His goitre had been observed as a baby and was treated with thyroid extracts until one month before being studied. Due to psycho-motor delay, he had been put in a centre for the mentally retarded. His voice was deep and his reasoning was slow with tardy responses. His skin was dry and rough and his pulse rate $65 / \mathrm{min}$. As shown in Table I, he had a $40 \mathrm{~g}$ soft goitre, undetectable total serum thyroxine $\left(\mathrm{T}_{4}\right)$, high serum thyroid stimulating hormone (TSH), almost unnoticeable ${ }^{131}$ I uptake at all times studied, with normal urinary iodine excretion during 24 hours. The ${ }^{131}$ I salivary/plasma (S/P) ratio was 1 . All these data fulfill the diagnostic criteria for complete iodide transport defect. The psychointellectual study by the Raven test placed him in percentile 5.

In May, 1973, treatment with potassium iodide in an $18 \mathrm{mg} / \mathrm{ml}$ solution was started (containing $1 \mathrm{mg}$ per drop). The initial iodine dose was $18 \mathrm{mg} /$ day, and later variations were established depending on the clinical evolution and analytical evaluation of thyroid func- 
Table 1 Clinical and analytical data of patients and mother at time of diagnosis

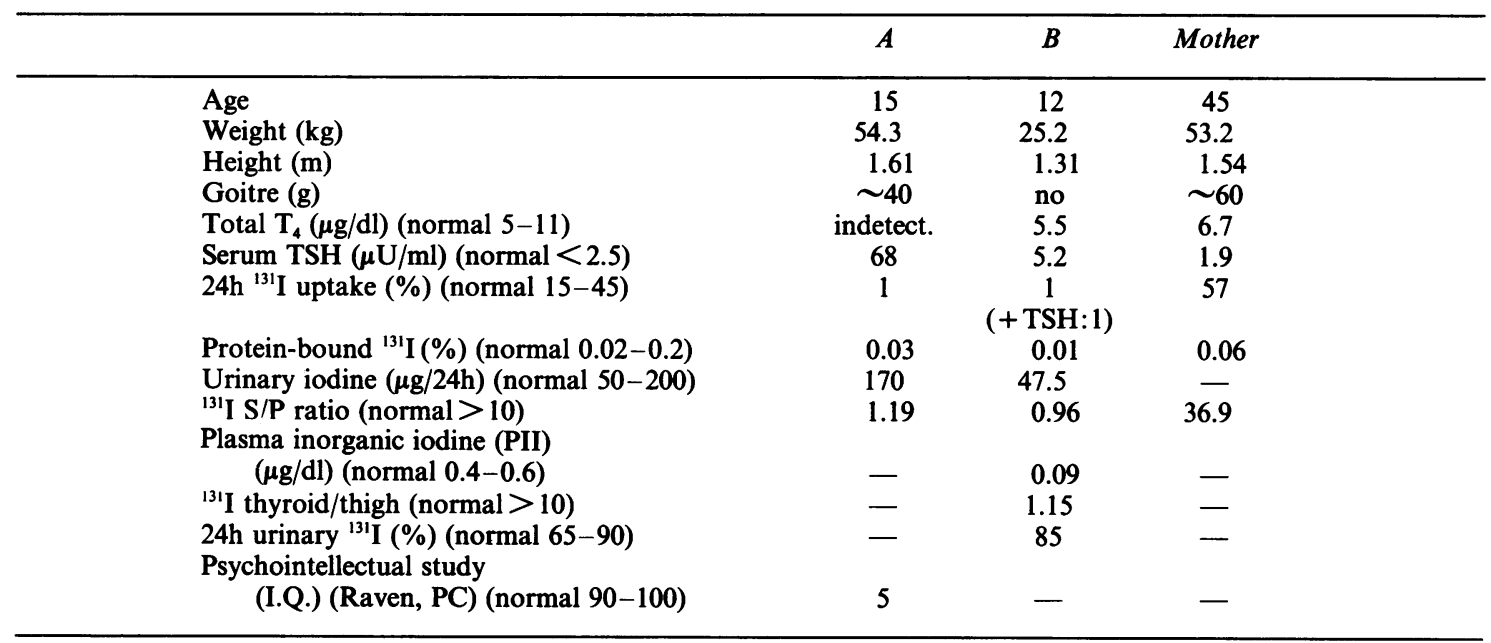

$\mathrm{S} / \mathrm{P}=$ salivary/plasma

tion, in order to reach euthyroidism. The goitre disappeared and his final height was $164.5 \mathrm{~cm}$.

Patient B was a 9 year old girl, sister of the patient A, diagnosed of congenital hypothyroidism at the moment of birth. She had been treated with thyroid extracts until one week before the study. She had no goitre and was only slightly mentally retarded. Total $\mathrm{T}_{4}$ was in the normal range and TSH was slightly elevated, $5.2 \mu \mathrm{U} / \mathrm{ml}$. Thyroid ${ }^{131} \mathrm{I}$ uptake was $1 \%$ and there was no change after exogenous TSH stimulation; $24 \mathrm{~h}$ urinary iodine excretion was normal. The salivary/plasma radioiodide ratio was 0.96 . These findings confirmed the same diagnosis as her brother's (see Table I). After the study, she was treated with $18 \mathrm{mg} /$ day iodine, the dose later varying depending on clinical evolution to reach normal clinical and analytical thyroid function. Menarche occurred at 12 years and her final height was $156 \mathrm{~cm}$. In September 1985 she became pregnant and iodide was therefore discontinued, replaced by $T_{4}$. Her daughter has neither hypothyroidism nor goitre.

The mother of patients A and B was also studied, because of goitre, but the ${ }^{131} \mathrm{I}$ uptake by the thyroid was normal and the salivary/plasma $(\mathrm{S} / \mathrm{P})$ radioiodide ratio was normal, 36.9, and she had normal serum thyroid hormone and TSH.

\section{Methods}

A TRH test was done giving $\mathbf{4 0 0} \mu \mathrm{g}$ synthetic TRH (PREM, Barcelona) in an intravenous bolus after an overnight fast. Total serum $T_{4}$, triiodothyronine $\left(T_{3}\right)$ and free $T_{4}$ were measured by RIA (Diagnostic Procedure Corporation) and TSH, growth hormone and prolactin were determined by standard commercial RIA (Sorin). S/P radioiodide ratio was calculated by measuring the radioactivity of saliva and serum aliquots collected after $50 \mu \mathrm{Ci}^{131} \mathrm{I}$ oral administration Protein-bound ${ }^{131}$ I was calculated by radioactive counting of the trichloroacetic acid precipitable materia after 24 hours of the ${ }^{131} \mathrm{I}$ trace dose. Total urinary iodine, plasma inorganic iodine (PII) or total serum iodine were measured according to the Benotti \& Benotti method. ${ }^{27}$

\section{Results}

Figure 1 shows biochemical results during treatment with iodide of the two patients over twelve and a half years (A) and eleven and a half years (B), respectively. Dosages varied between 10.3 and $22 \mathrm{mg} /$ day of iodine. Urinary iodine ranged between 9 and $17.1 \mathrm{mg} /$ day, and serum total iodine varied between 100 and $210 \mu \mathrm{g} / \mathrm{dl}$.

In both patients, $T_{4}$ and $T_{3}$ were in the normal range throughout the years of treatment, and, on a long term basis, there was a tendency for $T_{4}$ to change parallel to the amount of iodine given. When free $T_{4}$ was included in follow up treatment, it was in the normal range also. The TSH peak response to TRH was always in the normal range, and suppression never occurred, excluding hyperfunction at any therapeutic iodine dose.

Basal prolactin and its response to TRH, as well as basal growth hormone and cortisol and their response to exogenous hypoglycaemia, were normal during the treatment. 


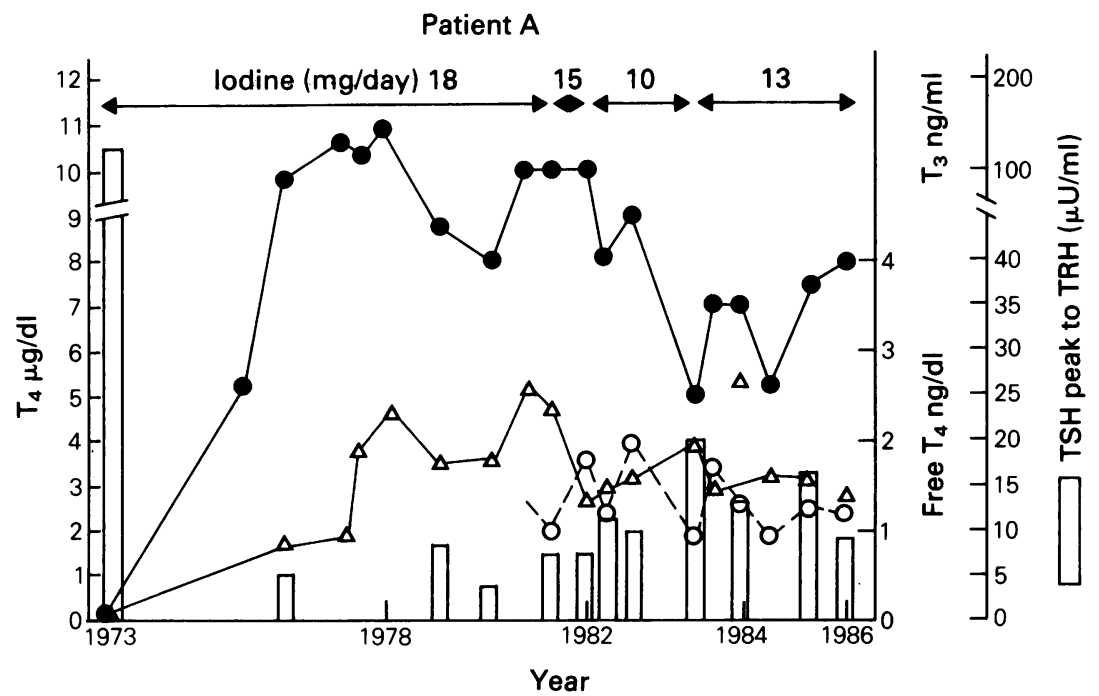

Patient B

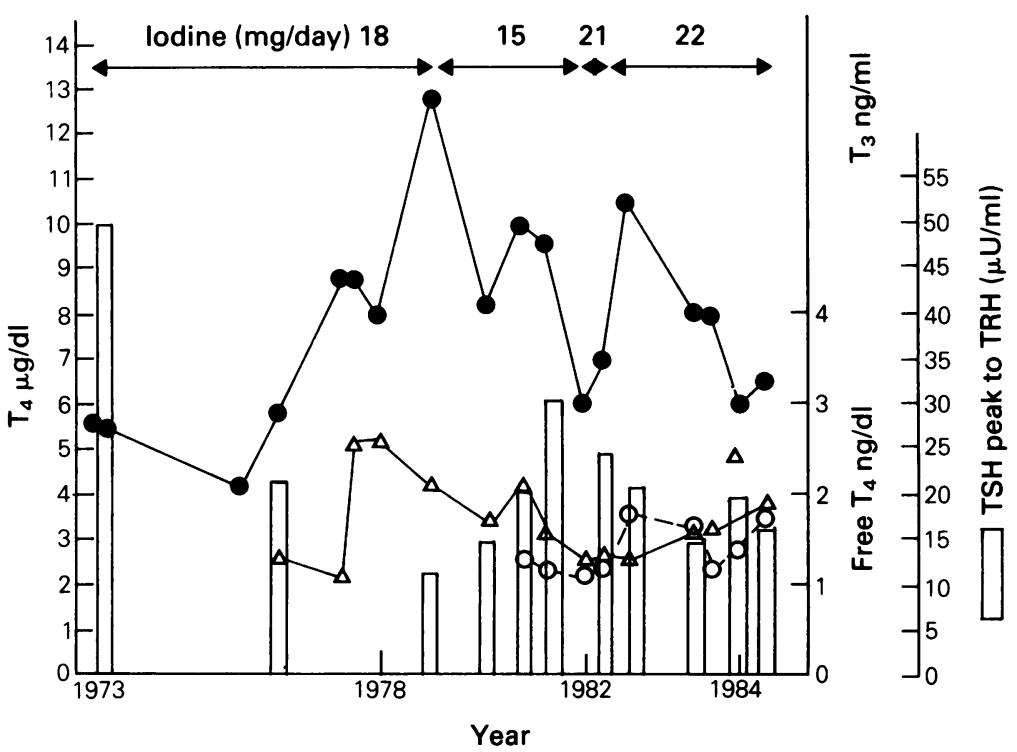

Figure 1 Iodine dose, total $T_{4}$ and $T_{3}$, free $T_{4}$ and TSH peak response to TRH during twelve and a half years (patient $\mathrm{A}$ ) and eleven and a half years (patient $\mathrm{B}$ ).

$0, \mathrm{~T}_{4} ; \mathrm{O} \longrightarrow$, free $\mathrm{T}_{4} ; \Delta \longrightarrow \Delta, \mathrm{T}_{3} . \mathrm{Q}, \mathrm{TSH}$ peak to TRH.

\section{Discussion}

In both siblings, the findings fulfil diagnostic criteria required to identify iodide transport defect ${ }^{1}$ : thyroid uptake very low or absent, not due to TSH defect or iodide contamination or exogenous thyroid hormone administration; iodide transport defect in saliva; and response to treatment with iodide. In untreated patients, the presence of differing degrees of goitre and hypothyroidism is usual. Patient $B$ had no goitre, nor 
hypothyroidism due to treatment with thyroid extracts from the time of birth until one week previous to the study. Other investigations and the later response to treatment excluded other causes of hypothyroidism.

Previously, only two families with siblings affected with this disorder have been described..$^{11.16}$ The rareness of this case and its low frequency in families make the establishment of a genetic transmission pattern difficult. The consanguinity described in other cases $^{2,11,13,16}$ has been excluded in our patients.

There is only one reported case with long term follow-up iodide treatment, which only lasted one year. ${ }^{19}$ The efficiency of this treatment in another patient for 20 years has been reported without details. ${ }^{1}$ In most other cases, after diagnosis, substitution therapy with thyroid hormones was carried out. This could be for practical reasons, because some authors consider iodide treatment to be more physiological. ${ }^{5,16}$

In previous reports euthyroidism was brought about with iodide doses between 2.3 and $100 \mathrm{mg} /$ day, ${ }^{16}$ or when total plasma iodide concentrations were 10 to $15 \mu \mathrm{g} / \mathrm{dl}{ }^{5,15}$ In only one case, the required dose was $63 \mathrm{mg} /$ day, with a plasma iodine concentration of $33 \mu \mathrm{g} / \mathrm{dl} .{ }^{19}$ Even with the widest range of iodide given to our patients, thyroid function was always normal, including at the lowest dose of $10.3 \mathrm{mg} /$ day. The

\section{References}

1. Stanbury, J.B. \& Dumont, J.E. Familial goiter and related disorders. In: Stanbury, J.B. \& Wyngarden, J.B. (eds) The Metabolic Basis of Inherited Disease. McGraw Hill, New York, 1983, pp 231-269.

2. Federman, D., Robbins, J. \& Rall, J.E. Some observations on cretinism and its treatment. N Engl J Med 1958, 259: $610-615$.

3. Stanbury, J.B. \& Chapman, E.M. Congenital hypothyroidism with goiter. Absence of an iodide-concentrating mechanism. Lancet 1962, i: 1162-1165.

4. Gilboa, Y., Ber, A., Lewitus, Z. \& Hasenfratz, J. Goitrous myxedema due to iodide trapping defect. Arch Intern Med 1963, 112: 212-215.

5. Wolf, J., Thompson, R.H. \& Tobbins, J. Congenital goitrous cretinism due to absence of iodide-concentrating ability. J Clin Endocrinol Metab 1964, 24: 699-707.

6. Gilboa, Y., Ber, A., Lwitus, Z., Lubin, E., Gordon, A. \& Stein, O. Goitrous myxedema with defect in iodide trapping and hormomogenesis. Isr J Med Sci 1966, 2: 145-151.

7. Kumahara, Y., Kimura, M., Oki, K., Toki, Y., Miyai, H. \& Uematsu, I. Hypothyroidism accompanied by huge goiter-iodide concentration deficiency type. Folia Endocrinol Jpn 1966, 42: 320-323.

8. Abe, H., Miyai, K., Kimura, K. et al. Goiter accompanying iodide concentration disorder. Sogo Rinsho 1967, 16: 1341-1344.

9. Struwe, F.E., Seseke, G., Kempe, H. \& Hoffman, G. Seltene Form der Hypothyreose bei Geschwistern highest doses did not have any of the previously described side effects, such as goitre with hypofunction, ${ }^{23}$ hyperfunction ${ }^{22,29}$ or thyroiditis. ${ }^{24,28}$ It is suggested that long term high plasma inorganic iodine concentrations produce no inhibitory effects on the biosynthesis of thyroid hormones. On the other hand, other authors have reported that by sharply raising plasma inorganic iodine up to $3900 \mu \mathrm{g} / \mathrm{dl}$, even for shorter periods of time ${ }^{5,19}$ such an effect was produced.

In agreement with others, in this study we have confirmed that hyperthyroidism does not occur with these long term high plasma iodide concentrations, ${ }^{15,16}$ although it has been found to occur in one case. ${ }^{4}$ Experimentally, hypothyroid dogs treated with iodide had follicular necrosis with massive loss of thyroid hormones into plasma ${ }^{24,28}$ Similar to other studies, no extra-thyroidal side effects were observed. ${ }^{30}$

In conclusion, iodide treatment in patients with iodide transport defect achieves normal thyroid function on a long term follow-up with no side effects.

\section{Acknowledgements}

We would like to thank Anna Steele for preparing this manuscript.
(Jodakkumulationsströrung). Monatsschr Kinderheilkd 1969, 117: 189-191.

10. Papadopoulos, S.M., Vagenakis, A.G., Moschos, A. et al. A case of partial defect of the iodide trapping mechanism. J Clin Endocrinol Metab 1970, 30: 302-307.

11. Medeiros-Neto, G.A., Bloise, W. \& Ulhoa-Cintra, A.B. Partial defect of iodide trapping mechanism in two siblings with congenital goiter and hypothyroidism. $J$ Clin Endocrinol Metab 1972, 35: 370-377.

12. Hamada, S., Kimura, L. \& Yawata, M. A case of iodide concentration disorder thyroid disease accompanied by citrullinemia. Nippon Rinsho 1974, 32: 2439-2441.

13. Kimura, K., Miyai, I., Kumahara, K. \& Uematsu, I. Hypothyroidism due to iodide concentration disorders. Nippon Rinsho 1974, 32: 2442-2444.

14. Matsuura, M., Nishihata, N., Kondo, M., Zenzaka, N. \& Suwa, S. An infant case of goitrous hypothyroidism due to iodide concentration disorders. Clin Endocrinol (Jpn) 1975, 23: 531-534.

15. Gershengorn, M.C., Wolff, J. \& Larsen, P.R. Thyroid pituitary feedback during iodine repletion. $J$ Clin Endocrinol Metab 1976, 43: 601-605.

16. Toyoshima, K., Matsumoto, Y., Nishida, M. \& Yabuuchi, H. Five cases of absence of iodide concentrating mechanism. Acta Endocrinol 1977, 84, 527 - 537.

17. Savoie, J.C., Leger, F.A., Doumith, R. \& Courpotin, C. Complete lack of active transport of iodide in congenital hypothyroidism, two unrelated cases. Ann Endocrinol 1977 (Abstract 28) 38: 16A. 
18. Pannall, P.R., Steyn, A.F. \& Van Reenan, O. Iodide trapping defect of the thyroid. A case report. $S$ Afr Med J 1978, 53: 414-416.

19. Dallot, C., Labrune, B., Courpotin, C., Leger, A. \& Grenet, P. Hypothyroidie par trouble congenital de la captation des iodures. Arch Fr Pediatr 1980, 37: 597601.

20. Saito, K., Yamamoto, K., Yoshida, S. et al. Goitrous hypothyroidism due to iodide-trapping defect. J Clin Endocrinol Metab 1981, 53: 1267-1272.

21. Wolff, J. Congenital goiter with defective iodide transport. Endocrine Reviews 1983, 4: 240-254.

22. Coindet, J.F. Nouvelles recherches sur les effects de l'iode et sur les precautions a suivre dans le traitment de goitre par ce nouveau remede. Ann Chem Phys (Paris) 1982, 16: 252-259.

23. Begg, T.B. \& Hall, R. Iodide, goitre and hypothyroidism. $Q J$ Med 1963, 32: 351-362.

24. Evans, T.C., Beierwalls, W.H. \& Nixhiyama, R.H.
Experimental canine Hashimoto's thyroiditis. Endocrinology 1969, 84: 641-646.

25. Editorial. Prevention and control of iodine deficiency disorders. Lancet 1986, ii: 315: 433-434

26. Sanchez-Franco, F., Garcia, M.D., Cacicedo, L., Martin-Zurro, A. \& Escobar del Rey, F. Influence of sex phase of the menstrual cycle on TSH response to TRH. $J$ Clin Endocrinol Metab 1973, 37: 736-740.

27. Benotti, J. \& Benotti, N. Protein bound total iodine and butanol extractable iodine by partial automation. Clin Chem 1963, 9: 408-416.

28. Belshaw, B.E. \& Becker, D.V. Necrosis of follicular cells and discharge of thyroidal iodine induced by administering iodide to iodine-deficient dogs. J Clin Endocrinol Metab 1973, 36: 466-474.

29. Conolly, R.J., Vidor, G.I. \& Stewart, J.C. Increase in thyrotoxicosis in endemic goiter area after iodation of bread. Lancet 1970, i: 500-502.

30. Steffer, G.E. Iodide fever. J A M A 1965, 192: 571-572. 